\title{
Europeanising Ideologies
}

\author{
Jonathan White \\ Professor of Politics, LSE
}

Forthcoming, Journal of European Public Policy

\begin{abstract}
This paper explores the relationship between ideology, the state and the transnational as it bears on European integration. Though typically studied in national contexts, ideologies and their clash have been Europe-wide since their emergence. As I argue, the European Union (EU) can be understood both as the continuation of these long-standing cross-border dynamics, and as the attempt to supersede them. Contemporary developments renew this dialectic. By exploring how ideology and European integration entwine, the paper underlines the value of a research agenda of heightened importance as the ideological hegemony of recent decades breaks down. ${ }^{1}$
\end{abstract}

The emergence of political ideologies tracked the emergence of the modern state. Accepting the ambiguities of definition and causality, a temporal overlap seems clear. Isms of diagnosis and prescription tied to groups of various kinds developed with the reorganisation of authority that brought the feudal period to a close. Whether in the guise of doctrines intended to legitimise new institutions, contest them in the name of self-determination, or restore the world that preceded them, ideologies came to the fore with the emerging state. Yet equally, ideologies were never likely to be constrained by state boundaries. Already in the late-eighteenth century, isms developed wider horizons, being extended to conflicts international in scope and deployed for cross-border constituencies. From the conflicts of the French Revolution to defences of empire, ideologies became a phenomenon of the transnational realm.

It is the extension of ideologies outwards from the state that this paper examines, with an eye in particular to European integration. Scholars typically approach ideology as a phenomenon of national settings, or else leave its sphere undefined (Bell 2002, p.224). Studies that set the likes of liberalism, socialism and conservatism in transnational context are rarer, like those of ideologies linked to transnational institutions (Martill 2017). Where scholars look beyond the state, it is often to the global level. Steger's work on ideologies and globalisation is one example (Steger 2009); studies of the ideologies of nineteenth-century empires (Bell 2013), of white racism (Lake and Reynolds 2008), global Islamism (Aydin 2017) or the United Nations (Thérien 2015) are others. Largely overlooked has been the space between the state and the global - ideologies in and of the regional. As one of the major experiments of the post-war era, the EU is a rich place to study ideologies transnational but less than global in extension. Their analysis remains under-developed in EU studies, something only now changing in the context of recent upheavals.

\footnotetext{
${ }^{1}$ For comments I thank Štefan Auer, Duncan Bell, Carlo Invernizzi Accetti, Fabio Wolkenstein, Lea Ypi, and three referees. The article was completed while on an Alexander von Humboldt Stiftung fellowship at the Hertie School, Berlin.
} 
Studying ideologies cross-nationally presents distinct problems given the opacity of the research object. To speak confidently of the existence and influence of an 'ism' is never easy, and the challenges look greater beyond the state, not just because ideologies have often been denied, but because of their frequent detachment from visible organisations, and the semantic ambiguities born of language diversity. But still they demand closer reflection. Such currents of thought tend to be amongst the most deeply-held, widespread and lasting, and also those closest to power. These are ideas oriented to action and underpinned by collectives (Freeden 1996, p.105), with the influence and durability this can bring. How the social world is signified, the opinions formed, the interests appraised, and their connection to institutions, are all matters in which ideologies are implicated. Even things treated as cultural givens, including (supra-)national identities, can be the legacy of ideological projects. Given the state of flux in Europe today, the significance of the form only increases.

As this paper argues, the EU has been built on ideology, and also against it. The Union is the expression of two countervailing tendencies. On the one hand, it is a continuation of the longstanding projection of ideologies across borders that has characterised Europe since the French Revolution. As the first section examines, the ideological conflicts of modern Europe typically unfolded on a regional stage, reflecting and consolidating a frame of reference (or 'imaginary') that was Europe-wide. European integration would mark the institutionalisation of those ideologies preeminent in these contests in a given period. On the other hand, and as the second section examines, the ideologies shaping the EU were defined exactly by their hostility to this wider pattern. They were efforts to transcend ideological conflict and its cross-border reverberations, informed by an idea of the supranational as a realm beyond ideological division. Initiated in an era of heightened anxiety about political isms, European integration was defined in contradistinction as an antiideological project, its institutions intended to escape such clashes.

The present period sees the former tendency renewed and the latter challenged. As the third section examines, whereas for decades the EU could be dissociated from isms and these ascribed to its critics, with increasingly regularity it meets the charge of being an ideological project itself. This is a form of politicisation where ideology and its attribution plays a central role. The section considers the specificity of critique on ideological grounds and its wider implications for the EU. In periods of 'interregnum' between one ideological settlement and another (Gramsci 1971, p.276; Stahl 2019), future trajectories may be more open. Whereas this threatens to break up an order designed to exclude rather than accommodate ideological conflict, it also points to a distinct rationale for supranational institutions: as an arena in which to regulate these cross-border conflicts. Such a role depends on institutions being separable from ideologies, and how far such a decoupling is possible remains one of the central questions in contemporary EU politics. 


\section{$\underline{\text { Ideology and the Modern European State }}$}

The first modern 'isms' were coined to describe heresies. Emerging in Reformation Europe, they were descriptions of religious doctrines advanced by their critics in the Catholic Church. Lutheranism, Calvinism, Puritanism and Anabaptism were amongst the first examples (Höpfl 1983, pp.1-2). For the pioneers of this pejorative rhetoric, isms denoted patterns of deviant thought and the ways of life said to attach to them. They evoked social groups, the '-ists' amongst whom these ideas were at home. While the attribution of shared belief was characteristic, its content could be a matter of debate, also indifference (Höpfl 1983, p.5). One of the functions of the idiom was to position the speaker as orthodox and rightful, and by highlighting distorted views, to reaffirm more generally the core tenets of the Catholic faith. The identification of heresy served the identification and protection of orthodoxy (Kurtz 1983).

The isms of early-modern Europe were used sporadically though, rarely being adopted by those they were said to describe. They were not ideology as we would come to know it, with its self-aware groups and political focus. To the extent they corresponded to real-world collectives, these were dispersed and weakly integrated, and their concerns mainly religious. Only in the eighteenth century did isms take on the characteristics we associate with ideology. In the years after the French Revolution especially, they became terms of self-description for those claiming likeminded views (Höpfl 1983, p.7), denoting idea-clusters centred on political interpretation and prescription. Spurred in part by the experience of revolution, with its suggestion of altered and alterable futures, collectives emerged defined by their transformative agenda. A new vocabulary developed centred on 'concepts of movement' (Koselleck 2004, pp.273ff.), as words like republic, liberty, and society came to define future-oriented projects of change.

Ideology as we shall understand it has its origins in this period (Freeden 1996, pp.141-2). ${ }^{2}$ It can be defined as patterned sets of ideas about the world as it is and as it should be, embraced by groups (often consciously as groups), and the basis on which they pursue some form of power (Freeden 1996, pp.22-3, p.105; Leader Maynard \& Mildenberger 2018). Such ideas find their most coherent expression in canonical texts and statements, but appear also in tacit and everyday contexts. While the pejorative connotations of early-modern isms have never been shed, accounts of ideology today tend not to define it in terms of deception and domination, close at hand though such effects

\footnotetext{
2 The same period saw the emergence of the concept of ideology (Strath 2013). Note also historiographical debates about how to conceive the preceding period, notably whether seventeenth-century thinkers like Locke were forerunners of liberalism (Bell 2014), and what debt was owed by republicanism to a longer tradition of republican thought (Koselleck 2004).
} 
may be. Emphasis is retained on its collective basis, whether in movements, parties or less visible groupings, and its practical orientation. We are dealing with ideas intended to shape the exercise of power, whether by direct application to decision-making institutions or by wider processes of contestation and de-contestation (Freeden 1996, p.77).

Analyses of the historical origins of ideology tend to emphasise processes of nation-stateformation. Steger connects ideology's appearance to the emergence of what he terms the 'national imaginary' - 'the taken-for-granted understanding in which the nation - plus its affiliated or to-beaffiliated state - serves as the communal frame of the political' (Steger 2009, p.9). This shared cultural space supplied the background ideas, symbols and reference-points on which ideologists drew. Liberalism, conservatism, socialism and their successors were built on this foundation, he suggests, and in turn replenished it as they were deployed in the nation's name. Steger's terminology is intended to highlight the novelty of more recent developments - the emergence of a global imaginary and its distinctive ideologies - but the primary suggestion is historical: that ideology in its formative period was inextricably linked to the national.

One needs to move carefully here, since speaking of national imaginaries risks positing the cultural unity that nationalists themselves tend to proclaim. One can slip from observing the centrality of nation-talk to accepting the reality of the community described. Surely correct though is that emerging discourses of nationhood provided a central object for contestation. Precisely because the nature, boundaries and interests of the nation were unclear, such concepts opened a space for competing interpretations. This revolutionary, secular language evoked a social world separable from political structures and with its own constituting power, contra divine-right theories and the unchanging communities supposed by traditional religion. Only then did it become possible to conceive doctrines of transformation and restoration, ones that would spark conflicts not least because the identity of that to be transformed was unclear.

To these symbolic shifts one may add the socio-economic upheavals of the period. As 'dislocation' theorists of nationalism have argued, the advance of the class structures of modern capitalism, accentuated by urbanisation and industrialisation, exposed people to new schemes of understanding (Gellner 1983). Ideas of nationhood were just some: 'it is here that the coining of numerous 'isms' belongs, serving as collective and motivating concepts capable of reordering and mobilizing anew the masses robbed of their place in the old order of estates' (Koselleck 2004). As communication and education structures developed, the constituency for such ideas expanded (Koselleck 2004, pp.251; Freeden 1999). Again, these transformations tracked processes of stateformation, as state representatives sought to steer, reinforce and take advantage of them. State institutions, increasingly defined and differentiated, enabled ideologies to take organised form (Freeden 1999). In political parties, ideologies found their clearest expression. 
The emergence of ideologies is inseparable then from the emergence of the modern state. Yet ideologies were never an intra-state phenomenon, even in the nation-state's heyday. Ideological politics has been cross-border in scope since its emergence, a source of enthusiasm and anxiety in part for this reason. ${ }^{3}$ Such tendencies were visible already in the heresies of the sixteenth century, often explicitly transcontinental in outlook (Baskerville 1994), given broad distribution by the papacy and the wider Catholic Church, and producing the first doctrinal wars by the seventeenth century (Pagden 2002, p.1). They are unmistakeable in the isms of the late-eighteenth century. The French Revolution, their catalyst, was recognised by contemporaries as of transnational status, like the conflicts it spawned.

Taking shape from the $1750 \mathrm{~s}$, the ideals of the French Revolution can be regarded, with all due caution about retroactive definition, as a brand of classical liberalism. As interrelated views about present conditions and their transformation, advanced by groups keen to imprint them on the exercise of power, they fit the definition of ideology well, albeit as an evolving combination of diverse intellectual strands, loosely centred on concepts of justice, reason and will (Baker 1990, Ch. 1; Hobsbawm 1997, pp.58-9; Sewell 1985, pp.74ff.; Rosenblatt 2018, pp.41ff.). Early revolutionaries sought constitutional monarchy on the British model - liberalism as anti-feudalism and anti-despotism, combined with an insistence on law and individual freedoms. From 1791, under the Girondins and Montagnards, the goals turned to abolition - liberalism as republicanism, combined with democratic ideas of equality (Haas 2005, p.46ff.; Cassels 2002, p.39; Cattaneo 1964). A constant throughout was that these were doctrines intended to travel (Hobsbawm 1997 p.54). Though proclaimed in the nation's name, the Declaration of the Rights of Man was phrased in abstract terms, evoking something more expansive than could be denoted by cultural criteria (Fontana in Pagden 2002, p.121; Hobsbawm 1997, p.65). Under the Girondins especially, spreading these ideals was an intrinsic goal; under the Montagnards, it seemed the best way to protect them at home (Cassels 2002, p.29).

As transnational as the revolutionaries' goals was the concern their actions sparked. Confronted with movements seeking rupture with the past, the makings of a conservative ideology took shape across Europe's centres of power. The Pillnitz Declaration of $27^{\text {th }}$ August 1791, authored by Prussia and the Holy Roman Empire, announced the condition of the French monarchy to be 'a situation of common concern for all sovereigns of Europe', and committed them to aiding the French king in restoring 'the foundations of a monarchical government'. ${ }^{4}$ Although reluctant to go to war,

\footnotetext{
${ }^{3}$ As will transpire, the transnational currents in ideology can take different forms: the cross-border spread of ideas and terminology (including ism labels), the widening of the constituency at whom they are aimed, the expansion of the movements they successfully inspire, their attachment to transnational institutional projects, or the conscious thematization of matters international in their content.

${ }^{4}$ http://www.emersonkent.com/historic documents/declaration of pillnitz $1791 . \mathrm{htm}$
} 
their position consolidated the beginnings of a cross-national ideological divide, one the Girondins were also keen to talk up with their own statements of principle to the international world. ${ }^{5}$

A central theme of nineteenth-century Europe was the periodic re-emergence of these ideological conflicts. Despite the variety of ideas across time and space, and internal disputes amongst friends of the Revolution concerning the militarism of the Napoleonic period, international affairs in the following decades can be grasped in terms of a liberal / conservative divide (Cassells 2002; Hobsbawm 1997 p.53; Rosenblatt 2018, pp.67ff.). As franchises were extended and parties consolidated, isms became habitual forms of self-definition, and the recurrence of the same labels across Europe added to the sense of equivalence between the conflicts described. Given its ease of translation and capacity to abstract from local groups and demands (Kurunmaki \& Marjanen 2018, p.247), ideologists aligning with an ism found themselves in possession of a vocabulary that could travel, one easily deployed to name a wider movement. ${ }^{6}$ Socialists especially took advantage, while liberals and conservatives sought to consolidate themselves cross-nationally against the Second International. As an historian observes, only 'the Franco-Russian alliance [of 1894] put to an end the right-left divide in international politics dating from 1791' (Cassels 2002, p.116) - and it did so only temporarily.

What these brief remarks suggest is the existence of a European imaginary, additional to the national frame. Ideologists of different persuasion pursued their ends with an eye to the wider European context. The ideologies they imputed to their adversaries, like principles they claimed for themselves, unfolded in an arena European in scale. For reasons of ideology, domestic politics was transnational and often the object of interference, sovereignty claims notwithstanding. This was why ideologies could be developed for export, and why certain European states, France most obviously, could come to be viewed as a crucible - a place where doctrinal conflicts of general significance unfolded, in the outcome of which outsiders felt implicated. For reasons both offensive and defensive, the outlook was decidedly transnational.

Different explanations are possible, one of them materialist. The French Revolution has been called a bourgeois revolution, given its leading concerns - with individual liberty, the rights of property holders, and the moral qualities of commerce - were those of an ascendant bourgeoisie (Hobsbawm 1997, pp.58-9, pp.234ff.; Abercrombie \& Turner 1978, p.156). It was a challenge to the feudal order raised by an emerging class of traders, opposed by the conservative aristocracy of the ancien regime. Given this commercial class was anything but nationally-bound, and a divide between bourgeoisie and aristocracy recurred across Europe, one could expect the same of liberal / conservative conflicts. Countries where the bourgeoisie was strongest, including Britain, France

\footnotetext{
5 See the 'Propagandist Decrees' of November / December 1792, offering 'fraternity and aid to all peoples who wish to recover their liberty': Haas 2005, p.51.

6 That labels may be more mobile than the ideologies they denote makes cross-border unity always fragile.
} 
and the Low Countries, saw middle-class liberalism triumph by the $1830 \mathrm{~s}$, and spread beyond Europe as the same class projected itself outwards with empires (Herzfeld in Pagden 2002). ${ }^{7}$ If, as the materialist view holds, ideology is produced when changing socio-economic structures need legitimation, the transnational processes of capitalist development unfolding across Europe invited this wider extension. ${ }^{8}$

But equally one may note factors more political. Expanding the 'scope of conflict' (Schattschneider 1975) so as to organise transnationally was often about overcoming domestic weakness. The internationalism of nineteenth-century socialists was inspired by the hegemony of liberals and conservatives in the major European states - in Mannheim's terms, it was not the ideology of established agents but the creative and destabilising 'utopia' of subaltern groups (Mannheim 1991). Projecting ideas across borders was a way to pursue transformations otherwise obstructed. To follow the fortunes of the like-minded abroad was also to track the progress of ideas that had become the basis of self-definition, and to seek confirmation that history would favour them. The transnational arena could have intrinsic significance, associated with universalist ambitions or structures like the Church and Carolingian empire. Such considerations might mix with defensive ones too. By forestalling the advance of opposing ideologies abroad, agents might aim to interrupt a momentum that, should it spread, would jeopardise their own de-contestations (Haas 2005, p.7). And to all these agentic considerations one may add the circulation of ideas unintentionally, without political aim, as concepts were deployed in new contexts, brought associations with them, and evolved in their encounter with new surroundings.

To speak of a European imaginary is not to deny the centrality of the national. All ideologies of the nineteenth century were interlaced with it in some way, either as could be traced to revolutionary ideals of liberty and self-determination, or as part of the counter-revolutionary tradition. But even those oriented to the good of one nation found reason to be concerned with tendencies further afield, and nationalism itself became something of a transnational ideology, a common frame given local content. Europe was not necessarily a strong leitmotif: it could be part of the assumed context without being a theme. Nor was the arena clearly bounded: its contours were expansive and contested, from the American Revolution to the Haitian Revolution, and the imperialist outlook that coloured nineteenth-century thought took the borders of 'Europe' far beyond the continent (Bell 2013; Armitage 1996; Rosenblatt 2018). Key to observe is an assumed frame of reference wider than the national yet short of the global - a template that in time would be adopted by Europe's critics too (Younis 2017). Ideology emerged in a regional frame.

\footnotetext{
${ }^{7}$ Cf. Marx and Engels (1974, p.64): the ideas of 'the ruling class are in every epoch the ruling ideas, i.e. the class which is the ruling material force of society, is at the same time its ruling intellectual force'.

${ }^{8}$ As pioneers of 'cleavage theory' would later observe, divisions of class were not the only kind to which ideologies might adhere (Lipset and Rokkan 1967).
} 
The post-national and the pursuit of the post-ideological

One reason this matters is because the making of the EU, as the effort to institutionalise certain ideologies of transnational ambition, can be seen as the extension of this pattern. The EU emerged from a hinterland of pan-European ideological politics that long predated it and of which it was a continuation. But this context matters also because these same transnational tendencies were a persistent source of dissatisfaction, encouraging the countervailing impulse to transcend them. Precisely because ideological politics had an explosive, cross-border character, interest was spurred in conceiving a world 'beyond' this. From a diversity of perspectives, the supranational sphere was cast as a realm detachable not just from nationalism but isms more generally. One of the motivations for European integration in the 1950s would be the desire to supersede ideological conflicts and the unstable system they generated. The EU was to be built in their counter-image.

Ideology entails a preoccupation with worlds preferable to the here and now, ${ }^{9}$ and transnational politics has always offered something to this sentiment. However much ideology- and state-formation went hand in hand, the world beyond the state has held fascination as a place of contrast. One sees this anticipated in the history of utopian thought, where places overseas traditionally functioned as the objects of imaginative projection. Before utopias were located in the future, they were located in faraway lands: the genre depended on the ultra-liminal for its imaginative horizon (Levitas 2011, pp.220-1). In the age of ideology the horizon was temporalized: the question became how the future could be different from the present. But the world beyond borders retained its importance, often signifying exactly the possibility of new beginnings. Pursuing ideological projects beyond the state became a way to cut loose from the inheritance of the recent past.

With the advent of the state, democracy and ideology, the world beyond the state could be conceptualised as a counter-realm to precisely these things. The transnational sphere, specifically the supranational, could be identified as a way to pursue projects defined in contradistinction to the state setting, detached from its associations, legacies and constraints. In strands of left-wing cosmopolitanism, notably expressed in the Ventotene Manifesto, this would mean departing from statist pathologies like fascism and chauvinist nationalism. For others, including thinkers of benevolent dictatorship and technocracy (Wells 2011 / 1933), it could mean escaping democratic and parliamentary processes. For others still, it could mean breaking with ideology itself, seeking a form of administration insulated from it. Two twentieth-century bodies of thought in which such

\footnotetext{
${ }^{9}$ Even conservatism tends to go beyond status-quo maintenance to seek the restoration of an idealised past.
} 
currents emerged, significantly for the later course of European integration, are Christian Democracy and economic liberalism. While both very much ideological formations themselves, descended from the conflicts of nineteenth-century Europe, they developed influential conceptions of the supranational shaped by aversion to ideology.

In strands of German Catholic thought adopted and adapted by Christian Democrats, the concept of the Abendland described a supranational space of shared values and faith that transcended the ideological divisions born of the French Revolution. Explicitly regional in focus, ${ }^{10}$ it was described in contradistinction to various ideologies and sub-themes subsumed under 'materialism', including liberalism, individualism, nationalism, fascism, socialism and communism (Mitchell 1995, pp.283ff.; Forlenza 2017, esp. p.278). The Abendland evoked the presumed oneness of Christian Europe prior to its fragmentation by ideology. The political task, as later construed by Christian Democrats, was to recreate the unity of this space, countering the isms dividing it from within (and sovereignty-system felt to support them) and those threatening it from without (notably from the East) (Mueller 2011, pp.132ff.; Forlenza 2017, pp.268ff.; Cellini 2018, p.81). Part of a long-standing counter-Revolutionary tradition, this body of thought was on the one hand a position within transnational ideological conflicts, on the other an effort to overcome them.

Liberal-economic thought in 1930s/40s Europe did not display the same religious commitments, ${ }^{11}$ but shared a conception of the supranational as a way to exit the destructiveness of ideological politics. From its inception, German Ordoliberalism had, in addition to its economic critique of monopoly-capitalism, a political critique of party democracy and the currents of mass opinion it expressed (Manow 2001, pp.181ff.). 'Demagogues spreading ideologies' (Biebricher 2017, p.107) were what these unfortunate arrangements were said to support. ${ }^{12}$ The alternative was to seek reinforced institutions of expertise where fact-based men of science could reign (Böhm, Eucken and Grossmann-Doerth 1936 / 2017, pp.27ff.), undisturbed by 'ideologists of the planned economy' (Eucken 1932 / 2017, p.70). Market-enabling policies would be built into an 'economic constitution' protected from political pluralism and its attendant instability (Gerber 1994, Bonefeld 2017). While for some this demanded nothing less than a global approach, others saw the merit of a regional approach based on European law (Slobodian 2018, pp.183ff.). In a related but distinct tradition, Austrian liberals such as Hayek also took interest in supra-state solutions, partly for the

\footnotetext{
10 The region corresponded broadly to the pre-Reformation Church; whether it extended to North America was a point of disagreement: Forlenza 2017, p.264, p.283.

11 The religious inspiration, if any, was generally Protestant (Manow 2001).

12 For Walter Eucken, this was a macro-historical story, traceable to how the democratic ideals of the French Revolution undermined the values they were meant to advance: 'For these ideologies there is a curious explanation. They affirm and promote movements that achieve exactly the opposite of that which ideologists hope from them. The democratisation of the world and the consequent unleashing of the demonic powers of peoples eliminated the old international politics of equilibrium, destroyed the political order of Europe and the world, sidelined the principle of peace, and created general insecurity.' (Eucken 1932 / 2017, p.69).
} 
very reason that they would be detached from the communitarian and egalitarian ideologies that shaped nation-state politics (Hayek 1939/1948).

By the mid-twentieth century one thus saw ideologies prescribing efforts to build a realm that would minimise ideological conflict. Hostility to totalitarian ideologies especially was pronounced - Christian Democracy and economic liberalism were movements of anti-socialism, anti-communism and anti-fascism first and foremost. But they also displayed a pronounced scepticism towards ideology as such, tied to an embrace of religious faith and spiritual values, or claims to be going beyond left and right. If often they recoiled from democratic institutions, it was because they considered mass politics inseparable from ideological tendencies. Nationalism was a central concern, but it was isms more generally they sought to transcend. While these sentiments would be shared by many in the 1950s, also in the US (Bell 1962), in Europe they acquired a spatial connotation that mapped onto the supranational sphere.

In an analysis of ideologies of the international, Bell distinguishes 'vertical' ideologies, focused on relations within a state, from 'horizontal' ideologies that address questions of the relations between and across them (Bell 2002, pp.223ff.). By the 1940s, economic liberalism and Christian Democracy had become horizontal in this sense, though they addressed something beyond the national and international. Defined against the state and its characteristic forms, theirs was a vision of the supranational. Consistent with the European imaginary inherited from previous generations, continental Europe was considered the place to initiate it. Whether to restore an earlier unity centred on Christendom and empire (Carolingian, Holy Roman, Habsburg) or consciously to break new ground, Europe was the assumed frame of reference.

The making of the EU can be seen as the institutionalisation, amongst other influences, of Christian Democracy and economic liberalism (Kaiser 2007; Bonefeld 2017). ${ }^{13}$ Many of the preoccupations of these ideologies, including their anti-ideological concerns, found expression in Europe's integration process and the views of those involved. Rarely perhaps are ideologies sufficient reasons for action, and motives often entwine. But the desire to maintain consistency with professed goals may encourage certain choices over others, and shape the meanings ascribed both by onlookers and actors (Skinner 2002). Figures such as Schuman, Adenauer, de Gasperi, Erhard, Müller-Armack, Hallstein, von der Groeben and Mestmäcker found in these traditions a repository of cultural and political-economic ideas about the supranational that could help rationalise practical steps of coordination. ${ }^{14}$

\footnotetext{
13 The EU is not the only example of the institutional embedding of ideology: the League of Nations was in many ways the institutionalisation of Wilsonian liberalism, pursued to restrain another internationalism (Leninism).

14 See e.g. Germany's Chancellor (Adenauer 1956) on the dangerous, French-Revolutionary doctrine of nationalism (p.8), the rise of the 'materialistic attitude' and 'mass-mindedness' (pp.12-13), and the deeper rationale behind the Coal and Steel Community (pp.12-14): 'The world cannot exist without a Christian and Occidental Europe. ... We want to save this Europe of ours. For Europe is in truth the mother of the world, and we are her children. ... The salvation of the Occident, the salvation of Christian culture, will be made possible only by an alliance among those
} 
Their hostility to ideological politics as they saw it meant those inspired by Christian Democracy and economic liberalism would often be drawn to organisational methods different to those found in the state. Rather than announce themselves in public forums as partisans under the banner of an ism, they would often seek less visible modes of association, particularly when coordinating transnationally. Informal circles of the like-minded formed in closed institutions, often aiming for executive and judicial rather than legislative power (Forlenza 2017, p.278; Kaiser 2007; Slobodian 2018). The diffuse structure of the EU realm, in part a reflection of the influence of these ideologies (Invernizzi Accetti 2019, ch. 4; White 2019, ch. 2), contributed further to masking the agency of those involved. Ideology is the basis on which groups pursue power, but whereas in the state this has tended to map onto centralised institutions that highlight actor-responsibility, the absence of formal hierarchy in the transnational sphere meant ideology would be dispersed across multiple structures and its agents harder to identify.

A striking feature of the EU's subsequent development would be the intermingling of ideologies and scholarship (White 2003). The organisational carriers of ideology in the nation-state have tended to be parties and related associations, but in the EU context this role would typically be played by intersecting circles of academia and bureaucracy, consolidating ideology's low visibility. Parties, conventionally, present their ideologies as such - as systematic diagnoses and prescriptions intended to influence power's exercise. Academics, scientists and bureaucrats tend not to. EU studies is not without isms - neofunctionalism, intergovernmentalism, federalism, constitutionalism and others mark traditions of both analysis and advocacy - but these have rarely been intended for mass consumption. They are of interest as the constructs of an intellectual elite, conceivably an avant-garde, but hardly as landmarks of public debate. By detaching themselves from the organisational structures that have tended to advertise ideology, the architects of the EU could better distance themselves from the ideological mode of politics they sought to avoid.

\section{Contesting the EU settlement}

For much of the last century, Europe has been the site of ambitious ideological projects centred on the design of shared institutions. The descendants of nineteenth-century ideologists saw opportunities in European integration to advance their visions and challenge foes. Either as a bridgehead to a global order, or as a distinctly regional entity, they sought a supra-national framework of some kind. If institutions can be seen as 'solidified political thought' (Müller 2011,

political forces whose basis is Christianity. If the Christian parties of Belgium, Germany, Holland, Italy, Luxemburg, Austria and Switzerland would establish a firmer alliance, with mutual exchange of information and mutual support, what a telling effect it would have upon events in Europe ...' 
p.243), the EU's basic framework reflects the influence of its makers. And yet, as we have seen, though ideological themselves, these projects were typically efforts at transcending ideology. The EU marks the intersection of two countervailing impulses.

Rather than the rendition of a single ideology, the post-War European order was the amalgam of several. The concepts on which it was built - freedom, growth, a 'market economy' that is also 'social' - were shared by more than one tradition. Indeed, the art of building transnational institutions has arguably required finding a language that those of different persuasion (Christian Democrats, economic liberals and others) might claim as their own. Partly because of this intermixing, but especially because of the contextual scepticism towards ideology, the currents in question have rarely been announced as such. There has been little desire to identify them publicly as isms and cultivate their wider recognition - rarely has the EU been sold to mass publics as a Christian-Democratic or liberal-economic project. Whether these ideologies ever percolated into general consciousness may be doubted: their societal reach has been more limited. These have been ideologies for elites rather than masses.

Legitimation of the EU to mass publics has generally emphasised material benefits. The common-market programme has been explained as a route to peace and prosperity - classically liberal concerns, but here cast as pragmatism and necessity (Schrag Sternberg 2013, ch. 1). EU representatives have cultivated notions of a common European interest, but one identifiable technocratically by 'independent' institutions (Vauchez 2016). Where the views of a European people have been evoked (Schrag Sternberg 2013, ch. 3), it has been as an aggregate of preferences to be identified by polling (e.g. Eurobarometer) rather than as integrated normative viewpoints. Much of the ideological production of the EU-sphere, particularly where it reflects the influence of coherent, self-standing traditions, has been inward-facing - a basis for like-minded elites to coordinate rather than to connect with a wider public.

One expression of the EU's casting as a post-ideological space lies in how popular disaffection has been classified and contained. The first modern isms were the names given to heresies by the Church, and it would not be far-fetched to draw a parallel. Controlling the meaning of dissent, even making it useful, has been an important goal for EU officials - a form of pre-emptive ideological politics. The concept of nationalism and the spectre of its 'return' has been a resource for supranationalists since the time of Coudenhove-Kalergi (Kettunen 2018, p.350, 360). Schuman himself used the term 'heresy' to describe nationalism in Europe (Forlenza 2017, p.273). More recently, the concept of euroscepticism - one that, like so many, migrates freely across scholarship and practice - has been used to denote deviations from EU support. Here as so often, an ism has been announced by its critics. Partly a scientific concept, euroscepticism is deeply political too, shaping the meaning of what it describes (Flood 2002). Defining things in terms of deviance from 
a reference standard will generally conflate different phenomena. Euroscepticism merges wholesale opposition to a European polity with opposition to the EU's structure and policies; left-wing with right-wing opposition; political critique with socio-cultural aversion; reasoned dislike with an emotional response. It conflates things whose unity lies mainly in the eye of defenders of the status quo, and equates transnational sympathy and solidarity with support for the EU in existing form. Such 'de-contestations' are ideological, but entail not so much endorsing a world-view as attributing one to others.

The making of the EU has been characterised then by the projection of ideologies across borders, coupled with open hostility to ideological politics. How, one might wonder, could it be otherwise? How could the EU not reflect the orientations of its makers, people of common beliefs building institutions largely from scratch; equally, how could its representatives not distance themselves from this fact, given the supranational sphere was meant to be an escape from politics as usual, and given the strategic risks of too partisan a project? Here is not the place to explore the problems connected: the blurring of value choices, rigidity before changing socio-economic circumstances, and the obscuring of agency. The difficulty of articulating larger visions of what the $\mathrm{EU}$ is for, and the need to supplement arguments from material benefit with those from emergency, are arguably effects of avoiding an ideological register. Deprived of the chance to draw on the prestige of political traditions, EU representatives have had to base their arguments on an aggregate of particularities, with the problems of narrativization that follow (White 2019, 2011). What can be highlighted here though is the significance of contemporary rejoinders - the critiques to which the EU has increasingly become prone, and in which ideology and the suspicion of it is central.

Just as ideologies have been pivotal to transnational institutions yet generally hidden from view, they have become pivotal to their condemnation. Much has been written on the EU's politicisation and the social cleavages that invite it, but ideology's significance is generally underplayed (de Wilde 2019). By those seeking to undo those institutions or reorient them, as well as by those wanting to add colour to a wider worldview, the EU has been denounced as an ideological project. Socialists, Greens, far-Right figures and others have condemned its institutions and policies not just as deficient but ideological - as instantiations of neoliberalism, cosmopolitanism, Catholicism, federalism and other isms. The 2005 French and Dutch referenda on an EU constitution brought such claims to the fore. Whereas the EU had long been criticised as undemocratic or 'sclerotic' (Schrag Sternberg 2013, pp.156ff) - with these attributions of ideology it could now be cast as symptomatic of wider problems.

Insurgent formations thereby take aim not just at particularities but the patterns these are said to embody. The EU has often been viewed as sui generis (one effect of the refusal to connect it with ideologies); to re-associate it with isms is to re-insert it into a larger history. It is to treat it 
as epiphenomenal of tendencies played out elsewhere. Indeed - to re-join Steger (2009) - critiques of this kind increasingly set the regional in a global space, with the EU cast as one more front in a clash with neoliberalism, globalism and the like. The EU becomes an expression of politics as elsewhere. Imputations of ideology thereby allow a more far-reaching politicisation of the EU than is achieved by targeting its specifics, and are the basis on which politicisation dynamics ripple across domestic, global and European settings (Zürn 2019, p.988).

By criticising the EU as the expression of an ism, such critics also suggest the influence of '-ists'. They present the EU as the outcome of someone's agency - as having been initiated by, or fallen under the sway of, certain groups and all that they represent. Such claims challenge those who, casting the Union as a space beyond ideology, have tended to remove agency and suggest an anonymous process responding to functional imperatives. (The reticence of EU officials in associating themselves with ideological labels allows their critics more freedom to attribute isms as they please.) It is important to acknowledge both the kernel of truth such critiques contain, and the extent to which they typically overshoot, presenting the EU as the offspring of a single ideology rather than a hybrid. By simplifying a complex reality, they invite counter-claims that perpetuate a cycle of contestation.

As critics denounce the EU as an ideological project, they sharpen lines of division and refashion the EU as the site of contending ideologies rather than the solidification of some. The end of the 'permissive consensus' reflects not just changes in the EU itself, increased non-majoritarian powers spelling increased contestation (Zürn 2019, p.989), but the re-contestation of the ideological settlement expressed in it. Perhaps one should not be too quick to identify the challengers as representing fully-fledged ideologies themselves, but - characteristically of such transition periods - their critiques restore the visibility of ideology and the expectation of it. They renew an idea of Europe as a conflictual arena, and of politics as the stuff of ideals and collectives, things the EU was conceived to depart from. Such moves may encourage established authorities to develop ideologies of self-justification, as advocates of 'liberal Europe' are beginning to.

We saw in the first section, discussing revolutionary France, the original form in which ideologies transnationalise, whereby a particular setting becomes a crucible of wider interest. A sense of shared predicament amongst the like-minded emerges, expressed in cross-border coordination, forms of intervention and imitation, and the migration of labels, concepts and narratives. Just as numerous episodes have extended this template, from the Spanish Civil War to the Cold War, one sees traces of it again in today's Europe. Cross-border interest in the standoff between the Greek government and the Eurozone Troika in spring 2015, and its interpretation as a conflict between Left and Right, or 'populists' and 'technocrats', is one example of the willingness to see particular sites as crucibles of something larger. 
Whereas the 1990s and 2000s saw renewed declarations of the end of ideologies (Brick 2013), more recently these seem hard to sustain. Ideological alternatives to the status quo remain ill-developed, but public consent seems weaker. Institutions and policy regimes endure, but their intellectual underpinnings look weaker, challenged by both left-wing and nationalist internationalism (Stahl 2019). Evolving in the shadow of European integration, these latter have in turn been shaped by it: ideologies have been Europeanised, just as they have been mechanisms of Europeanisation. Is self-identification with ideological politics returning too? This is less clear, yet plausible. In contemporary critiques of technocracy, conspiracy, compromise and lost sovereignty, one detects the desire for clarity, purpose and commitment. Such are the qualities traditionally sought in isms, and many far-Right groups, Greens and Leftists seem inclined to capitalise by casting themselves as ideas-based traditions transnational in scope. Once the refuge of those seeking to escape ideology, the supranational sphere begins to look like the heart of it once more.

On an optimistic reading, out of the dual tendencies to project ideologies across borders and to build transnational institutions against this, a valuable synthesis is possible. A logical reason for supranational institutions to exist is to give platform to the transnational ideological divides that predate and evolve with them. One might look to the EU precisely to institutionalise the 'imagined' European arena of conflict that has existed for more than two centuries. Quite contrary to the reasons for which it was initiated, one might rationalise the Union as a way to allow the orderly expression and adjudication of long-standing cross-border ideological conflicts, and seek to reshape its institutions accordingly. Arguments for a stronger European Parliament, as the place where transnational parties can take root, build on such reasoning. But these readings depend on EU structures being more than the instantiation of ideologies themselves: whether such a decoupling is truly possible remains one of the central questions in EU politics.

\section{$\underline{\text { Conclusion }}$}

Ideological politics was European in scale from the moment the French Revolution became a wider example. These events gave expression to a European imaginary - a Europe-wide frame of reference for principled struggles - that encouraged cross-border mobilisations and interventions. The EU is a legacy of these long-standing dynamics, whilst also inspired by dissatisfaction with them. It has opened up new fronts of ideological politics - as a conduit for their influence on supranational institutions and policies; as the source of new labels advanced to control the meaning of dissent; and as an object of critique on ideological grounds. Ideology, and the suspicion of it, has been central to how the EU has developed. 
The border-leaping tendencies of ideological politics are one reason it has often been feared. In addition to the usual concerns about rigidity of thought, here it threatens to mobilise at the expense of the institutions and ties of the nation-state. The ambitions get grander, the need for compromise perhaps weaker. And when ideologies are inserted into supranational structures, and in the name of taking distance from ideological conflicts, they may be consequential yet hard to discern. Rather than associated with public-facing entities such as parties and legislatures, they have tended to be buried in law, interlocking bureaucratic and academic circles, and executive institutions. The groups underpinning ideology have often been informal, and keen to cast supranational administration as a space beyond ideology. At least for a period, their claims may be decontested more thoroughly.

But as more recent events indicate, such a settlement is precarious. The institutionalisation of ideologies can be doubled-edge. Though in some ways the apogee of an ideological project, hegemony can be a source of weakness, as diagnoses and prescriptions become taken for granted and under-theorised in the absence of challengers. The very capacity to detach ideological projects from mechanisms of mass participation leaves them vulnerable as circumstances change and consent to new arrangements is sought. As the EU and its ideological underpinnings are contested, they become more visible. One possible outcome is that Europe becomes an arena of ideological conflict once more, with the EU's institutions formalising the 'imagined' European arena that has existed since the late eighteenth century.

The pursuit of ideological projects on a transnational scale seems unlikely to disappear, and the Union's demise would surely not terminate it. Something like a European imaginary, and increasingly something more expansive still, would presumably persist, just as it long preceded the EU. Ideals of national sovereignty promise non-interference, and for those dissatisfied with the contemporary EU, the nation-state seems to promise an escape of sorts. Reversing the relation characteristic of the twentieth century, the nation-state has become the site of utopian projection, a place of extrication from the ills and constraints of the transnational. But for as long as ideological conflict can still be observed or imputed across borders, non-interference seems fanciful. The politics of the nation-state was never national in extension, and is unlikely to be so in future. What remains to be determined is how the cross-border tendencies of ideology will unfold, and to the benefit of which kinds of project.

\section{$\underline{\text { References }}$}

Abercrombie, Nicholas and Bryan Turner (1978), 'The Dominant Ideology Thesis', British Journal of Sociology 79 (2), pp.149-70.

Adenauer, Konrad (1956), World Indivisible: With Liberty and Justice for All, trans. R. and C. Winston (London: Allen \& Unwin).

Armitage, David (1996), The Ideological Origins of the British Empire (Cambridge: CUP).

Aydin, Cemil (2017), The Idea of the Muslim World: a global intellectual history (Cambridge MA: Harvard UP). 
Baker, Keith (1990), Inventing the French Revolution: Essays on French Political Culture in the Eighteenth Century (Cambridge: CUP).

Baskerville, Stephen (1994), 'Protestantism as Transnational Ideology', History of European Ideas 18 (6) pp.901-11.

Bell, Daniel (1962), The End of Ideology: On the Exhaustion of Political Ideas in the Fifties (Cambridge, MA: Harvard UP).

Bell, Duncan (2014), 'What is Liberalism?', Political Theory, 42 (6), pp.682-715.

-- (2013), 'Ideologies of Empire', in Freeden, Sargent and Stears (eds.) Oxford Handbook of Political Ideologies (Oxford: OUP).

--- (2002), 'Anarchy, power and death: contemporary political realism as ideology', Journal of Political Ideologies 7 (2), pp.221-239.

Biebricher, Thomas (2017), 'Ordoliberalism as a Variety of Neoliberalism', in Josef Hien and Christian Joerges (eds.) Ordoliberalism, Law and the Rule of Economics (Oxford: Bloomsbury).

Böhm, Franz, Walter Eucken and Hans Grossmann-Doerth (1936 / 2017), 'The Ordo Manifesto of 1936', in Thomas Biebricher and Frieder Vogelmann (eds.) The Birth of Austerity: German Ordoliberalism and Contemporary Neoliberalism (London: Rowman \& Littlefield), pp.27-39.

Bonefeld, Werner (2017), The Strong State and the Free Economy (Lanham: Rowman \& Littlefield).

Brick, Howard (2013), 'The End of Ideology Thesis', in Freeden et al. (eds.), Oxford Handbook of Political Ideologies (Oxford: OUP).

Cassells, Alan (2002), Ideology and International Relations in the Modern World (London: Routledge).

Cattaneo, Mario (1964), Il partito politico nel pensiero dell'illuminismo e della rivoluzione francese (Milan: Giuffrè).

Cellini, Jacopo (2018), 'The Idea of Europe at the Origins of the European People's Party', Journal of European Integration History 24 (1), pp.79-94.

De Wilde, Pieter (2019), ‘The making of four ideologies of globalization', European Political Science Review 11 (1), pp.1-18.

Eucken, Walter (1932 / 2017), 'Structural Transformations of the State and the Crisis of Capitalism', in Biebricher and Vogelmann (eds.) The Birth of Austerity (London: Rowman \& Littlefield), pp.51-72.

Flood, Chris (2002), 'Euroscepticism: a problematic concept', paper presented to UACES 32 ${ }^{\text {nd }}$ Annual Conference, Belfast, 2-4 September.

Forlenza, Rosario (2017) 'The Politics of the Abendland: Christian Democracy and the Idea of Europe after the Second World War', Contemporary European History 26 (2), pp.261-286.

Freeden, Michael (1999), 'The “Beginning of Ideology” Thesis', Journal of Political Ideologies 4 (1), pp.5-11.

--- (1996), Ideologies and Political Theory (Oxford: OUP).

Gellner, Ernst (1983), Nations and Nationalism (Oxford: Blackwell).

Gerber, David (1994), 'Constitutionalizing the Economy: German Neo-Liberalism, Competition Law and the “New” Europe', American Journal of Comparative Law 42 (1), pp.25-84.

Gramsci, Antonio (1971), Selections from the Prison Notebooks, trans. Quintin Hoare and Geoffrey Nowell Smith (London: Lawrence and Wishart).

Haas, Mark (2005), The Ideological Origins of Great Power Politics, 1789-1989 (Ithaca: Cornell UP).

Hayek, Friedrich (1939 / 1948), 'The Economic Conditions of Interstate Federalism', in Hayek, Individualism and Economic Order (London: Routledge).

Hobsbawm, Eric (1997) The Age of Revolution: 1789-1848 (London: Weidenfeld \& Nicolson).

Höpfl, H. M. (1983), 'Isms', British Journal of Political Science 13 (1).

Kaiser, Wolfram (2007), Christian Democracy and the Origins of European Union (Cambridge: CUP).

Kettunen, Pauli (2018), 'The Concept of Nationalism in Discussions on a European Society', Journal of Political Ideologies 23 (3), pp.342-69.

Koselleck, Reinhart (2004), Futures Past: On the Semantics of Historical Time (New York: Columbia).

Kurunmäki, Jussi and Jani Marjanen (2018), 'Isms, ideologies and setting the agenda for public debate', Journal of Political Ideologies 23 (3).

Kurtz, Lester (1983), 'The Politics of Heresy,' American Journal of Sociology 88, pp.1090-91.

Maynard, Jonathan Leader and Matto Mildenberger (2018), 'Convergence and Divergence in the Study of Ideology: A Critical Review’, British Journal of Political Science 48 (2), pp.563-89.

Lake, Marilyn and Henry Reynolds (2008), Drawing the Global Colour Line:

Levitas, Ruth (2011), The Concept of Utopia (Oxford: Peter Lang).

Lipset, Seymour and Stein Rokkan (1967), 'Cleavage structures, party systems, and voter alignments: an Introduction', in Lipset and Rokkan (eds.) Party systems and voter alignments: cross-national perspectives (New York: Free), pp.1-64.

Mannheim, Karl (1991), Ideology and Utopia (Abingdon: Routledge).

Manow, Philip (2001), 'Ordoliberalismus als ökonomische Ordnungstheologie', Leviathan 29 (2), pp.179-198.

Martill, Benjamin (2017), 'International ideologies: paradigms of ideological analysis and world politics', Journal of Political Ideologies, 22 (3), pp.236-255.

Marx, Karl and Friedrich Engels (1974), The German Ideology, 2nd edn, ed. C. J. Arthur (London: Lawrence and Wishart). 
Mitchell, Maria (1995), 'Materialism and Secularism: CDU Politicians and National Socialism, 1945-1949', Journal of Modern History 67 (2), pp.278-308.

Pagden, Anthony (2002) (ed.), The Idea of Europe: From Antiquity to the European Union (Cambridge: CUP).

Rosenblatt, Helena (2018), The Lost History of Liberalism: from ancient Rome to the twenty-first century (Princeton: PUP).

Schattschneider, E. E. (1975), The Semisovereign People: a Realistic View of Democracy in America (Hinsdale: Dryden P.).

Schrag Sternberg, Claudia (2013), The Struggle for EU Legitimacy, 1950-2005 (Basingstoke: Palgrave MacMillan).

Sewell, William (1985), 'Ideologies and Social Revolutions: Reflections on the French Case', Journal of Modern History 57 (1), pp.57-85.

Skinner, Quentin (2002), Visions of Politics, Vol. 1: Regarding Method (Cambridge: CUP).

Slobodian, Quinn (2018), Globalists: The End of Empire and the Birth of Neoliberalism (Cambridge MA: Harvard UP).

Stahl, Rune Moeller (2019), 'Ruling the Interregnum: Politics and Ideology in Nonhegemonic Times', Politics and Society.

Steger, Manfred (2009), The Rise of the Global Imaginary: Political Ideologies from the French Revolution to the Global War on Terror (Oxford: OUP).

Stråth, Bo (2013), 'Ideology and Conceptual History', in Freeden et al. (eds.), Oxford Handbook of Political Ideologies (Oxford: OUP), pp.3-19.

Thérien, Jean-Philippe (2015), 'The United Nations ideology: from ideas to global politics' Journal of Political Ideologies, 20 (3).

Vauchez, Antoine (2016), Democratizing Europe (Basingstoke: Palgrave Macmillan).

Wells, H. G. (2011 / 1933), The Shape of Things to Come (London: Gollancz).

White, Jonathan (2019), Politics of Last Resort: Governing by Emergency in the European Union (Oxford: OUP).

White, Jonathan (2011), Political Allegiance after European Integration (Basingstoke: Palgrave Macmillan).

White, Jonathan (2003), 'Theory Guiding Practice: the Neofunctionalists and the Hallstein EEC Commission', Journal of European Integration History 9 (1), pp.111-131.

Younis, Musab (2017), "United by blood”: race and transnationalism during the Belle Époque', Nations and Nationalism 23 (3), pp.484-504.

Zürn, Michael (2019), 'Politicization compared: at national, European, and global levels', Journal of European Public Policy 26 (7), pp.977-995. 